Journal of Economics and Behavioral Studies

Vol. 5, No. 4, pp. 226-236, April 2013 (ISSN: 2220-6140)

\title{
Gender differences in Working Capital Management amongst Small Business Owners in Uganda
}

\author{
Laura A. Orobia \\ Makerere University Business School, Kampala, Uganda \\ lorobia@mubs.ac.ug
}

\begin{abstract}
The purpose of this study is to examine gender differences on the effect of individual attributes on working capital management amongst small business owners. Based on a sample of 360 owner-managers of small businesses in the central business district of Kampala, the results show as follows. There are significant gender differences in perceived usefulness and attitude. Secondly, males and females do not statistically differ in terms of impulsivity. Thirdly, perceived usefulness significantly influences working capital management for females but not males. Fourthly, attitude significantly influences working capital management for males but not females. Lastly, the effect of impulsivity on working capital management is stronger for females than males. However, paucity of studies on the input perspective of working capital management limited crossvalidation of the findings with previous research. Future studies should be conducted to confirm the results. At policy level, understanding gender differences on the effect of the identified driving forces should be of interest to practitioners and policy makers in their effort to enhance small business management through developing appropriate gendered policies. This study contributes to the dearth of evidence of working capital management literature by investigating the effect of individual attributes as opposed to the conventional financial ratios.
\end{abstract}

Keywords: Working capital management, gender differences, perceived usefulness, attitude and impulsivity

\section{Introduction}

There is growing acceptance among scholars that women entrepreneurship is the engine that drives the economies across nations. Not only do they contribute to employment creation and economic growth through their increasing numbers, but women also make a contribution to the diversity of entrepreneurship in the economic process (Verheul, Stel \& Thurik, 2006). In 2010, the Global Entrepreneurship Monitor (GEM) ranked Uganda as the sixth most entrepreneurial country in the world. However, the GEM findings reveal less women participation in entrepreneurship compared to their male counterparts (Namatovu et al., 2010). This is indicated by the Total Entrepreneurial Activity indexes of 35.5 (for men) and 30.3 (for women) in 2009, compared to 32.2 (for men) and 30.5 (for women) in 2010. Furthermore, the predominant business typology in Uganda is small businesses (Ernst \& Young, 2011), of which $40 \%$ is women owned (UBOS, 2012). Notably, $30 \%$ of the businesses in Uganda close down before one and half years of operations, especially among the small businesses where women play a significant role (Namatovu et al., 2010; Walter et al., 2004). One of the factors that may explain the failure of small businesses to celebrate the first anniversary is poor working capital management behavior (Ekanem, 2010; Kazooba, 2006). Poor working capital management amongst women business owners can be attributable to the fact that they are often held back by the task and institutional environment. More specifically, the current environment in Uganda is characterized by market failures, technology advancement and deficiencies in institutional arrangements (Briggs, 2009; Stevenson \& St-Onge, 2005; Munene, 1991). Such environment affects women's access to capital, technology, education, professional business development services and other economic resources More so, women are traditionally homemakers and responsible for childrearing, which in turn renders them part-timers in business. In such circumstances, women are faced with the challenge of balancing available time between their gender roles and the business. Consequently, lack of time for their businesses tends to be a persistent problem. In relation to this, women have limited socialization circles, and this affects their access to knowledge, basic business skills, attitude and resultant behavior (Crawford \& Marecek, 1989). Basing on these insights, gender differences in working capital management behavior are inevitable. 
In view of the fact that management of small businesses revolves around the owner-manager, the individual attributes such as perceived usefulness, attitude and impulsivity are likely to influence their actions. Moreover, the attributes are expected to differ between men and women. For instance, Venkatesh and Morris (2000)'s study showed that men consider perceived usefulness to a greater extent than women when making decisions on usefulness or productivity-related factors of a new technology. The researchers add that men are more driven by instrumental factors than women. On examining gender differences in attitude towards financial management, Hira and Mugenda (2000) indicate that females hold negative attitude than their male counterparts. Similarly, Dittmar et al., (1995) found that females have higher tendency to act impulsively without much analytical thinking than males. These factors put female business owner-managers at a higher risk of having financial problems than their male counterparts (Weir \& Willis, 2000; Dowling, Copur \& Hoiles, 2009). Although previous studies that have examined gender differences regarding these attributes are found in other domains, we know very little about the differences in working capital management context. Understanding gender differences on the effect of individual attributes on working capital management behavior amongst owner-managers of small businesses should be of interest to practitioners and policy makers in their efforts to enhance small business management. Based on the discussion above, this study investigates gender differences on the effect of individual attributes on working capital management, amongst owner-managers of small businesses in Uganda. The rest of the paper is structured as follows: The next section discusses working capital management and individual attributes. This is followed by a description of the approach that was adopted to collect and analyze the data. The results are presented thereafter. The last section comprises of discussions of findings, conclusions and implications.

\section{Literature Review}

Working capital management: A large body of literature exists on working capital management studies (see Afza \& Nazir, 2007; Deloof, 2003; Filbeck \& Krueger, 2005; Lazaridis \& Tryfonidis, 2006; Padachi, 2006; Raheman \& Nasr, 2007; Teruel \& Solano, 2007). The studies conceptualize working capital management as the planning and controlling of inventory, accounts receivable, cash and accounts payable. The objective of managing working capital is to ensure that organizations are able to meet their short-term obligations when they fall due and to avoid excess investment in current assets (Padachi, 2006; Teruel \& Solano, 2007). According to Teruel and Solano (2007), firms need to emphasize efficient working capital management because it affects profitability. Over investment in inventory ties up the firm's capital and this reduces profits. In addition, it increases holding costs such as theft, obsolescence and opportunity, while little investment results into stock out costs and less sales. Over investment in accounts receivable may increase sales in the short run but increase bad debts in the long-run. In terms of cash, too much cash increases risks associated with holding cash, while too little cash leads to cash problems. Therefore, organizations need to ensure optimum level of working capital at all times (Padachi, 2006). The finance literature is replete with studies that investigate working capital management using financial ratios (Deloof, 2003; Filbeck \& Krueger, 2005; Lazaridis \& Tryfonidis, 2006; Padachi, 2006). The studies provide a general outlook of working capital management at the expense of supply-side forces such as individual attributes. Notably, a few studies have investigated gender differences in financial management in particular (Hira \& Mugenda, 2000; Falahati \& Paim, 2011) and yet, working capital management involves the management of inventory, receivables, cash and payables. This study therefore, sought to investigate the differences between male and female business owners in relation to working capital management, which has hitherto been ignored.

Perceived usefulness: According to Davis (1989), perceived usefulness is defined as the degree to which a person believes that using a particular system would enhance his or her job performance. Similarly, Mathwick, Rigdon and Malhotra (2001) define perceived usefulness as the extent to which a person deems that a particular system will boost his or her job recital. In the same way, Menon and Kahn (2002) and Childers et al. (2001) define perceived usefulness as consumers' perceptions of functional and utilitarian dimensions. Further insights are provided by Venkatesh (2000) and, Moutinho and Smith (2000) who refer to perceived usefulness as an individual's perceptions that using a system enhances the outcome of its usage. All these definitions link well with the expectancy theory that argues that the choice to initiate a particular course of action is influenced by the expectation that an action will lead to valued outcomes. This implies that when owner-managers perceive working capital management will lead to the desired outcomes, this perception will propel them to undertake the routines. One of the aspects in which men and women differ in 
behavior is their orientation. According to Venkatesh and Davis (1996), men are more task-oriented than females. Consequently, men will consider performance expectancy while effort expectancy is more salient for women. Previous studies on gender differences in perceived usefulness have tended to focus on IT adoption and usage. For instance, Venkatesh and Morris (2000) sought to explain gender differences in IT adoption. They found that men consider perceived usefulness to a greater extent than women when making decisions on usefulness or productivity-related factors of a new technology and those men are more driven by instrumental factors than women. The findings are in agreement with Shashaani and Khali (2001) who found that males are more assertive and therefore tend to be more task-oriented than females. Working capital management involves different tasks associated with planning, monitoring and control of inventory, receivables, cash and payable. Although this may be seen as a task oriented function, the women may be propelled by their ability to perform the tasks. It is therefore, expected that the effect of perceived usefulness on working capital management is stronger for male owner-managers of small businesses than females.

Attitude: Attitude refers to the extent to which a person perceives behavior in a favorable or unfavorable light (Ajzen, 1991). In the same vein, Leonard et al. (2004) states that attitude involves judgment whether the behavior is good or bad and whether the user is in favor of or against engaging in the behavior. Accordingly, when people evaluate a given behavior positively, they are very likely to engage in the said behavior. In the finance domain, several scholars have reported the relationship between money attitudes and level of financial problems (Dowling, Corney \& Hoiles, 2009; Hayhoe et al., 2000; Lea et al., 1995; Lim, Teo, \& Loo, 2003; Tokunaga, 1993) financial satisfaction in adults (Tang, 1995; Wilhelm, Varcoe, \& Fridrich, 1993) and financial management behavior (Chau et al., 2004) studies. The studies corroborate the relationship between attitude and behavior. Regarding gender differences, Ventakash and Davis (1991)'s study, provide empirical evidence showing that men are more likely to consider the value of money, financial activities and performance than women. They concluded that men have stronger and more positive attitude towards internet banking than women do. In the same spirit, Falahati and Paim (2011) state that financial management is portrayed as more appropriate to males than females. The males are viewed as bread earners and are charged with the role of providing for the family (Falahati \& Paim, 2011). As such, they are encouraged by society to engage in financial management behavior such as investing, saving and budgeting (Newcomb \& Rabow, 1999; Gutter, Copur \& Garrison, 2009; Hira \& Mugenda, 2000; Falahati \& Paim, 2011). Accordingly, males are expected to be assertive and independent. The pattern is not the same for the females because they are not encouraged to be assertive and independent. Drawing from the financial socialization process, Hira and Mugenda (2000) assert that females are more likely to hold negative attitude toward financial management and to engage in poor financial management behavior than males. Based on these insights, it can be argued that attitude toward working capital management involves considering the value of performance activities or behavior. Therefore, it is expected that the effect of attitude on working capital management is stronger and positive for male owner-managers of small businesses than their female counterparts.

Impulsivity: Zuckerman, Kuhlman, Joireman, Teta and Kraft (1993) discuss impulsivity in terms of a general model of personality. The scholars describe impulsivity as an individual's trait that involves lack of planning and the tendency to act impulsively without thinking. Impulsivity has been associated with personal finance (Dittmar et al., 1995) and money management (Chau et al., 2004; Kidwell et al., 2003). For example, Chau et al. (2004) found a negative relationship between dysfunctional impulsivity and financial management practice. In the same spirit, Kidwell et al. (2003) found that individuals who scored low in impulsivity engaged in marinating a financial budget (money management). The studies suggest that impulsive tendencies are associated with irresponsible behavior, which consequently lead to poor financial management behavior. In consumer buying behavior studies, impulsivity is associated with hedonic experiences. The studies indicate that impulse buying occurs when a customer experiences a sudden powerful and persistent urge to buy immediately (Rook, 1987). This provides further support for the relationship between impulsivity and behavior. On examining gender differences in impulsivity, Dittmar et al. (1995) found that men and women process the information differently, buy different items for different reasons, and have different influences on purchase decisions. Individuals have built-in spending mechanism: desire to buy and ability to control an urge to buy. Some studies indicate that women have less self-control and thus are more susceptible to impulse spending (Mischel \& Ayduk, 2004). This is because women tend to shop for hedonic reasons compared to men; consequently women tend to buy unplanned items. Lack of 
planning and careless spending are associated with poor financial management. This means that high degree of impulsive tendencies is likely to worsen working capital management in small businesses. Along the insights above, it is expected that the effect of impulsivity on working capital management is stronger and negative for female owner-managers of small businesses than their male counterparts. Whereas previous studies indicate that females differ from their male counterparts in terms of perceived usefulness, attitude and impulsivity, they are limited to domains other than working capital management. This study contributes to working capital management literature by introducing the individual attributes through a gender lens. Thus, the following hypotheses are tested:

$H_{1}$ : $\quad$ Male and female owner-managers of small businesses differ in terms of perceived usefulness, attitude and impulsivity.

$\mathrm{H}_{2}$ : $\quad$ Perceived usefulness significantly influences working capital management for male than female ownermanagers.

$\mathrm{H}_{3}: \quad$ Attitude significantly influences working capital management for male than female owner-managers.

$H_{4}$ : Impulsivity significantly influences working capital management for female than male ownermanagers.

\section{Methodology}

Research design and sample: This study employed a cross sectional survey design, and is confined to small businesses employing between 5-50 workers. A sample of 360 small business owners was drawn from ventures located in Kampala (capital city of Uganda) using the Uganda Bureau of Statistics Business Register (2007). This region was chosen because it is the commercial heartland where most of the business activities take place. In addition, the business model in this region is predominantly the small businesses (Kazooba, 2006; UBOS, 2012). The participants were selected using systematic random sampling technique after which, data were collected through a personal approach and a response rate of $80 \%$ was achieved. The data collection approach was chosen because the limited availability and efficiency of postal and communication services in Uganda, could not allow questionnaires to be mailed, faxed or couriered to respondents without causing selection bias.

Operationalization and measurement of variables: The items used in the development of the data collection instrument were generated from previous instruments but modified where necessary to suit the study context. The continuous variables were anchored on a 6-point scale. Operationalization of the study variables are presented in table 1.

Table 1: Operationalization of the study variables

Variable/ Issues to examine
Perceived usefulness
The degree to which a person believes that
engaging in the behavior in question would
enhance the desired outcomes

\section{Attitude}

Person's evaluation of behavior in a favorable or unfavorable light

\section{Impulsivity}

Person's tendency to act with relatively little forethought

\section{Working capital management}

The discrete actions/ activities involved in planning, monitoring and control of inventory, receivables, cash and payables

\section{Literature}

Cheong \& Park (2005); Chiu et al. (2005); Davis (1989); Liao \& Cheung (2002); Luarn \& Lin (2005); Wang et al. (2003); Venkatesh \& Morris (2000).

Ajzen (1991); Ing-Long \& Jian-Liang (2005); May (2005); $\mathrm{Lu}$ et al. (2003); Ramayah et al. (2005); Rhodes \& Courneya (2003).

Chau et al. (2004); Dickman (1990); Kidwell et al., (2003); Zuckerman et al. (1993)

Ajzen (1991); Chau et al. (2004); Kidwell et al. (2003) 
Using the Cronbach's alpha coefficients, the internal consistency results obtained are; Perceived usefulness $=0.71$, Attitude $=0.74$, Impulsivity $=0.72$ and Working capital management $=0.81$. All the values obtained exceeded the acceptable value of 0.7 (Nunnally, 1978).

Data analysis: Data was cleaned, followed by parametric assumptions diagnostic tests. The results showed that the parametric assumptions were met. Descriptive statistics were used to determine the sample characteristics. T-tests were performed to determine gender differences in perceived usefulness, attitude and impulsivity. To test the conceptual model assumed in the current study, a regression analysis was performed. The results are presented next.

\section{Results}

This study sought to investigate gender differences on the effect of perceived usefulness, attitude and impulsivity on working capital management, amongst small business owner-managers.

Sample characteristics: The descriptive statistics in table 4 (appendix) shows that males were more (233) than females (127), with the majority belonging to the 29 - 39 age bracket ( $M=55 \% ; F=43 \%)$. Both males and females attained A' level (secondary school) as their highest level of education (M=22\%; $F=25 \%)$. Majority of females (51\%) had not received financial training compared to the male counterparts (37\%). Both males and females had past experience in business $(\mathrm{M}=81 \%$; $\mathrm{F}=80 \%)$. In terms of business sector, majority of females (41\%) are found in the hotel and restaurant business, while majority of males (40\%) are found in trade. These statistics are consistent with previous Global Entrepreneurship Monitor - Uganda survey reports (Namatovu et al., 2010; Walter et al., 2004) and the Uganda Bureau of Statistics abstract 2012. Further support is from Orobia, Sserwanga and Rooks (2011) who established similar gender differences in sample characteristics.

T-test results: Gender differences in perceived usefulness, attitude and impulsivity were tested using t-tests. The mean scores, standard deviations, t-statistics and significance test are shown in table 2.

Table 2: Descriptive statistics and t-test results

\begin{tabular}{lllllll}
\hline \multirow{2}{*}{ Variables } & \multicolumn{2}{l}{ Females $(n=127)$} & \multicolumn{2}{l}{ Males $(n=233)$} & \multicolumn{2}{l}{} \\
\hline Mean & SD & Mean & SD & T & Sig \\
\hline Perceived usefulness & 5.0 & .49 & 5.2 & .52 & -3.59 & $.000^{* *}$ \\
Attitude & 5.2 & .57 & 5.3 & .53 & -2.55 & $.011^{*}$ \\
Impulsivity & 4.1 & 1.1 & 4.4 & 1.1 & -1.83 & .068 \\
\hline
\end{tabular}

Significance ${ }^{*} p<.05,{ }^{* *} p<.0001$

Perceived usefulness: Perceived usefulness scale reflected the degree to which the individuals perceived engaging in working capital management would enhance the desired outcomes. Table 2 shows that perceived usefulness mean scores were 5.0 for female and 5.2 for male owner-managers of small businesses. The mean comparison of $t$-test indicates a significant gender difference in the perceived usefulness score $(t=-3.59$, $\mathrm{p}<.0001$ ) between females and males. This implies that females and males differed significantly in terms of perceived usefulness.

Attitude: The attitude scale reflected the degree to which the individuals evaluated the various working capital management activities in a favorable or unfavorable light. The results show that attitude mean scores were high for males (5.3) than females (5.2). The mean comparison of t-test indicates a significant gender difference in attitude score $(\mathrm{t}=-2.55, \mathrm{p}<.05)$ between females and males. This implies that females and males differed significantly in terms of attitude.

Impulsivity: Impulsivity scale reflected the tendencies to act with relatively little forethought. The results show that impulsivity mean scores were 4.1 for female and 4.4 for male owner-managers of small businesses. The mean comparison of $t$-test indicates a non-significant gender difference in the impulsivity score ( $t=-1.83$, $p>.05$ ) between females and males. This implies that females and males do not statistically differ in terms of 
impulsivity. The above results clearly demonstrate that the mean scores for males were higher than females. These results are consistent with previous findings (Chowdhury \& Endres, 2005; Gatewood et al., 2003; Shashaani \& Khali, 2001; Venkatesh \& Morris, 2000) that confirm existence of gender differences. This study therefore, provides empirical evidence supporting the hypothesis stating that male and female ownermanagers of small businesses differ in terms of perceived usefulness and attitude. The hypothesis of gender differences in impulsivity was not supported.

Regression analysis: Gender differences on the effect of individual attributes on working capital management were examined using separate regression analysis for females and for males. The results are presented in table 3.

For females: The results in table 3 indicate that perceived usefulness and impulsivity are not only in the direction predicted, but significantly explain $23 \%$ of the variance in working capital management. Further analysis shows that perceived usefulness is the strongest predictor $(\beta=.377, \mathrm{p}<.001)$ for females followed by impulsivity and attitude respectively.

Table 3: Regression analysis results

\begin{tabular}{lllllll}
\hline \multicolumn{1}{l}{} & B & Std. Error & Beta & R & R $^{2}$ & ${\text { Adj } \mathbf{R}^{2}}^{2}$ \\
\hline Females & & & & .477 & .227 & .209 \\
Constant & 2.234 & .661 & & & & \\
Perceived usefulness & $.565^{* * *}$ & .138 & .377 & & & \\
Attitude & .129 & .118 & .101 & & & \\
Impulsivity & $-.19^{* *}$ & .053 & -.289 & & & \\
Males & & & & & & \\
Constant & 2.663 & .536 & & .329 & .108 & \\
Perceived usefulness & .145 & .108 & .101 & & & \\
Attitude & $.380^{* * *}$ & .106 & .272 & & & \\
Impulsivity & $-.094^{*}$ & .045 & -.136 & & & \\
\hline
\end{tabular}

Dependent variable - Working capital management; ${ }^{*} p<.05,{ }^{* *} p<.01,{ }^{* * *} p<.0001$

For Males: The results in table 3 show that attitude and impulsivity are in the direction predicted, and they both significantly explained $11 \%$ of the variance in working capital management behavior. This prediction rate is half that of females. The results also show that attitude is the strongest predictor $(\beta=.272, p<.001)$ for males followed by impulsivity and perceived usefulness respectively.

In summary the hypothesis that;

- Perceived usefulness significantly influences working capital management for males than females were not supported.

- Attitude significantly influences working capital management for males than females was supported

- Impulsivity significantly influences working capital management for females than males was supported

Discussion: This study provides empirical evidence on the factors that affect working capital management amongst female and male business owner-managers. It was established that perceived usefulness has a significant influence on working capital management for females but not males. This is an interesting finding given that previous studies established mixed results. For instance, Venkatesh and Morris (2000)'s study showed that men consider perceived usefulness to a greater extent than women when making decisions on usefulness or productivity-related factors of a new technology. Similarly, Venkatesh and Davis (1996) established that the effect of perceived usefulness on internet banking was significant in males than females. The studies allude that men tend to pay attention to job performance expectancy than women do. In contrast, Gefen and Straub (1997)'s study indicated that women rate the usefulness of e-mail higher than men do because, e-mail enhances women's communication and social presence. A plausible explanation for the 
current finding can be attributable to the effect of gender roles. In Uganda, most women in businesses are part-time self-employed because of their roles as homemakers and childrearing (Namatovu et al., 2010). Consequently, they tend to have less time for their businesses. In such circumstances, women are very likely to value activities that are time saving and are guided in their actions by this 'time saving' perspective than men. This suggests that for women, working capital management behavior improves when they believe it will improve the desired outcomes. This seems not to be the case for men.

The study result indicates that attitude has a significant influence on working capital management behavior for males but not females. In Uganda, most businesses are dominated by men; the men start businesses at an early age and have more business networks than their female counterparts (Sserwanga, 2011). Consequently, the men are more exposed to business operations and have social peers who may impact of how they run their businesses. In the process, the men gain more understanding of not only what things happen, but how and why. Such experiences provide an edge for men in that it shapes and strengthens their beliefs in business operations. Based on these insights, it can be argued that business exposure enables males to depend more on their beliefs for developing attitude toward a behavior in question. In contrast, females are affected by social norms and expectations, and therefore, rely less on their beliefs when forming attitude toward a behavior in question. The results further indicate that impulsivity has a significant influence on working capital management for both females and males. However, the beta coefficient is higher for females $(\beta=-29)$ than for males $(\beta=-.14)$, suggesting that impulsivity has a weaker effect on working capital management for males than for females. This is consistent with previous studies that indicate that the effect of impulsivity on a behavior is more significant in females than in males (Dittmar et al., 1995). Impulsivity, variously expressed as a lack of planning, too quick responding, inability to delay gratification and poor inhibitory control, is associated with poor financial management habits. As Youn (2000) clearly put it, without the power of selfcontrol, people give in to desires and impulsive behavior occurs. However, some studies reveal lack of gender differences in impulsivity between males and females (Patton et al., 1995; Reynolds et al., 2006).

\section{Conclusion and Implications}

The findings and discussion above leads to the conclusion that, factors that influence working capital management in small businesses differ for females and males. More specifically, perceived usefulness is a critical factor for females as attitude is for males. This means that working capital management behavior for females improves when they believe the behavior will yield the desired outcomes. On the other hand, when males evaluate working capital management as something important, we begin to see their improvement in working capital management behavior. This implies that it is erroneous to assume 'blanket' factors affecting how owner-managers manage their working capital. The need to examine gender based behavior and supply-side forces cannot be overemphasized. From the theoretical aspect, the key contribution the study makes, relates to the observation earlier made that there has been insufficient knowledge in the empirical research focusing on gender differences on the effect of individual attributes on working capital management. In this regard, the study validates the theoretical assertions that people's actions are driven by their perceptions and beliefs; and that this differs for men and women. Paucity of studies on the supply-side forces of working capital management limited comparison of the findings with previous research. Therefore, future studies should be conducted to confirm the results in a different setting. The study findings has a number of managerial and policy implications. It provides empirical evidence showing the strong predictors of working capital management through a gender lens. More specifically, perceived usefulness makes a significant contribution to working capital management for females. In contrast, attitude makes a significant contribution to working capital management for males.

These are critical factors that owner-managers should consider in determining possible changes to enhance working capital management. At the policy level, the policy makers and other stakeholders need to develop keen interest in designing gendered policies and programs to cater for not only the small businesses' needs but also the differences in gender groups. This study focused on selected individual attributes such as perceived usefulness, attitude and impulsivity, and thus the average predictive power was $20 \%$, implying that the remaining $80 \%$ of the variance may be explained by other factors that were not considered in this study. Future studies should consider other individual attributes such as level of education, age, previous experience and self-efficacy. Secondly, although a survey questionnaire was used to collect data through a personal 
approach, follow up interviews which would have informed us of the reasons why the respondents held certain views were not undertaken. Employing a qualitative approach would be beneficial. Finally, the present study is cross-sectional. The views held by individuals may change over the years. This suggests that future studies should employ a longitudinal approach to test the robustness of the model. In spite of its limitations, this study reliably makes important contributions as discussed above. Future research may wish to replicate in different country contexts.

\section{References}

Afza, T. \& Nazir, M. S. (2007). Working Capital Management policies of firms: Empirical evidence from Pakistan. In the proceedings of the $9^{\text {th }}$ South Asian Management Forum (SAMF) on February 24- 25. North South University, Dhaka. Bangladesh.

Ajzen, I. (1991). The theory of planned behavior. Organizational Behavior and Human Decision Processes, $50(2), 179-211$.

Briggs, B. R. (2009). Issues affecting Ugandan indigenous entrepreneurship trade. African Journal of Business Management, 3(10), 786-797.

Chau, A., Chan, F. \& Chan, Y. K. (2004). Study on financial management practices on University students in Hong Kong.

Cheong, J. H. \& Park, M. C. (2005). Mobile internet acceptance in Korea. Internet Research, 15(2), 125-140.

Childers, T., Carr, C., Peck, J. \& Carson, S. (2001). Hedonic and utilitarian motivations for online retail shopping behavior. Journal of Retailing, 77(4), 511-538.

Chiu, Y. B., Lin, C. P. \& Tang, L. L. (2005). Gender differs: Assessing a model of online purchase intentions in etail service. International Journal of Service Industry Management, 16(5), 416-435.

Chowdhury, S. \& Endres, M. (2005). Gender difference and the formation of entrepreneurial self-efficacy. Presented at the United States Association of Small Business (USASBE) Annual Conference, Indian Wells, CA.

Crawford, M. \& Marecek, J. (1989). Psychology Reconstructs the Female: 1968-1988. Psychology of Women Quarterly, 13, 47-165.

Davis, F. D. (1989). Perceived Usefulness, perceived ease of use, and user acceptance of information technology. MIS Quarterly, 13, 319-340.

Davis, F. D. Bagozzi, R. P. \& Warshaw, P. R. (1989). User acceptance of computer technology: A comparison of two theoretical models. Management Science, 35(8), 982-1003.

Deakins, D., Morrison, A. \& Galloway, L. (2002). Evolution, financial management and learning in the small firm. Journal of small Business and Enterprise development, 9(1), 7-16.

Deloof, M. (2003). Does working capital management affect profitability of Belgian firms? Journal of Business Finance \& Accounting, 30(3/4), 573-588.

Dickman, S. J. (1990). Functional and dysfunctional impulsivity: personality and cognitive correlates. Journal of Personality and Social Psychology, 58, 95-102.

Dittmar, H., Beattie, J. \& Friese, S. (1995). Gender identity and material symbols: Objects and decision considerations in impulse purchases. Journal of Economic Psychology, 16(3), 491-511.

Dowling, N. A., Corney, T. \& Hoiles, L. (2009). Financial Management Practices and Money Attitudes as Determinants of Financial Problems and Dissatisfaction in Young Male Australian Workers. Journal of Financial Counseling and Planning, 20(2), 5-13.

Ekanem, I. (2010). Liquidity management in small firms: a learning perspective. Journal of Small Business and Enterprise development, 17(1), 123-138.

Ernst, L. \& Young, K. (2011). 2010 Baseline survey of Small and Medium Enterprises in Uganda. Draft Final Report 2011, Print. Uganda Investment Authority.

Fahati, L. \& Paim, L. H. (2011). Gender differences in financial wellbeing among college students. Australian Journal of Basic and Applied Sciences, 5(9), 1765-1776.

Filbeck, G. \& Krueger, T. M. (2005). An analysis of working capital management results across industries. Mid American Journal of Business, 20(2), 11-18.

Gatewood, E. J., Carter, N. M., Brush, C. G., Greene, P. G. \& Hart, M. M. (2003). Women Entrepreneurs, Their Ventures, and the Venture Capital Industry: An Annotated Bibliography, Stockholm: ESBRI (a publication of the Diana project). 
Gefen, D. \& Straub, D. W. (1997). Gender differences in the perception and use of e-mail: An extension to the Technology Acceptance Model. MIS Quarterly, 21(4), 389-400.

Gutter, M. S., Copur, Z. \& Garrison, S. (2009). Which Students Are More Likely to Experience Financial Socialization Opportunities? Exploring the Relationship between Financial Behaviors and Financial Well-Being of College Students (pp. 1-31). Indiana: Networks Financial Institute, Indiana University.

Hayhoe, C. R., Leach, L. J., Turner, P. R., Bruin, M. J. \& Lawrence, F. C. (2000). Differences in spending habits and credit use of college students. The Journal of Consumer Affairs, 34(1), 113-133.

Hira, T. K. \& Mugenda, O. M. (2000). Gender Differences in Financial Perceptions, Behaviors and Satisfaction. Journal of Financial Counseling and Planning, 13(2), 86-92.

Ing-Long, W. \& Jian-Liang, C. (2005). An extension of trust and TAM model with TPB in the initial adoption of on-line tax: an empirical study. International Journal of Human-Computer Studies, 62(6), 784-808.

Jarvis, R., Kitching, J., Curran, J. \& Lightfoot, G. (1996). Financial Management of Small Firms. Association of Chartered Certified Accountants, London.

Kazooba, C. T. (2006). Causes of business failure in Uganda: a case study of Mbarara and Bushenyi towns. African studies quarterly, 8(4).

Kidwell, B., Brinberg, D. \& Turris, R. (2003). Determinants of Money management behavior. Journal of Applied Social Psychology, 33(6), 1244-1260

Lazaridis, I. \& Tryfonidis, D. (2006). Relationship between working capital management and profitability of listed companies in the Athens Stock Exchange. Journal of financial management and analysis, 19(1), 26-35.

Lea, S. E. G., Webley, P. \& Walker, C. M. (1995). Psychological factors in consumer debt: Money management, economic socialization, and credit use. Journal of Economic Psychology, 16, 681-701.

Lim, V. K. G., Teo, T. S. H. \& Loo, G. L. (2003). Sex, financial hardship and locus of control: An empirical study of attitudes towards money among Singaporean Chinese. Personality and Individual Differences, 34, 411429.

Luarn, P. \& Lin, H. H. (2005). Toward an understanding of the behavioral intention to use mobile banking. Computers in Human Behavior, 21, 873-891.

Mathwick, C., Rigdon, E. \& Malhotra, N. (2001). Experiential value: conceptualization, measurement and application in the catalog and Internet shopping environment. Journal of Retailing, 77(1), 39-53.

May, O. S. (2005). User acceptance of internet banking in Penang: a model comparison approach. MBA thesis, School of Management, University Sains Malaysia, Penang.

Menon, S. \& Kahn, B. (2002). Cross-category effects of induced arousal and pleasure on the Internet shopping experience. Journal of Retailing, 78(1), 31-42.

Mischel, W. \& Ayduk, O. (2004). Willpower in a cognitive-affective processing system: The dynamics of delay of gratification. In K.D. Vohs \& R.F. Baumeister (Eds.), Handbook of self-regulation: Research, theory, and applications (99-129). New York: Guilford Press

Moutinho, L. \& Smith, A. (2000). Modeling bank customers' satisfaction through mediation of attitudes towards human and automated banking. International Journal of Retail \& Distribution Management, 18(3), 124-134.

Munene, J. C. (1991). Organizational environments in Africa: a factor analysis of critical incidents. Human Relations, 44, 439-458

Namatovu, R., Waswa, B., Kyejjusa, S. \& Dawa, S. (2010). Global Entrepreneurship Monitor (GEM Uganda) Executive report.

Newcomb, M. D. \& Rabow, J. (1999). Gender, Socialization, and Money. Journal of Applied Social Psychology, 29(4), 852-869.

Nunnally, J. (1978). Psychometric Theory. New York: McGraw-Hill.

Orobia, L., Sserwanga, A. \& Rooks, G. (2011). Risk taking and start-up capital: Exploring gender differences in Uganda, through an international comparison. Journal of Economics and Behavioral Studies, 3(2), 83-93.

Padachi, K. (2006). Trends in working capital management and its impact on firms' performance: an analysis of Mauritian small manufacturing firms. International Review of Business Research Papers, 2(2), 45 -58.

Patton, J. H., Stanford, M. S. \& Barratt, E. S. (1995). Factor structure of the Barratt impulsiveness scale, Journal of Clinical Psychology, 51 (6), 768-774.

Raheman, A. \& Nasr, M. (2007). Working capital management and profitability-case of Pakistani Firms. International Review of Business Research Papers, 3(1), 279-300. 
Ramayah, T., Ling, C. Y., Norazah, M. S. \& Ibrahim, M. (2005). Determinants of intention to use an online bill payment system among MBA students. E-Business, 9, 80-91.

Reynolds, B., Ortengren, A., Richards, J. B. \& de Wit, H. (2006). Dimensions of impulsive behavior: Personality and behavioral measures. Personality and Individual Differences, 40(2), 305.

Rhodes, R. E. \& Courneya, K. S. (2003). Investigating multiple components of attitude, subjective norm, and perceived control: an examination of the theory of planned behavior in the exercise domain. The British Journal of Social Psychology, 1(42), 129-46.

Rhodes, R. E. \& Courneya, K. S. (2003). Modeling the theory of planned behavior and past behavior. Psychology, health and medicine, 8(1), 57-59.

Rook, D. W. (1987). The buying impulse. Journal of Consumer Research, 14, 189-199.

Rosa, P., Kodithuwakku, S. \& Balunywa, W. (2006). Reassessing Necessity Entrepreneurship in Developing Countries. Institute for Small Business \& Entrepreneurship, 1-13.

Shashaani, L. \& Khalili, A. (2001). Gender and computers: similarities and differences in Iranian College Students' attitudes toward computers. Computers and Education, 37(3), 363-375.

Stevenson, L. \& Annette, S. O. (2005). Support for Growth-oriented Women Entrepreneurs in Uganda. African Development Bank (AfDB) · Tunis, 2005

Sserwanga, A. (2011). Entrepreneurial quality in Uganda. Unpublished PhD thesis. Makerere University, Uganda.

Tang, T. L. P. (1995). The development of a short money ethic scale: Attitudes toward money and pay satisfaction revisited. Personality and Individual Differences, 19, 809-816.

Tokunaga, H. (1993). The use and abuse of consumer credit: Application of psychological theory and research. Journal of Economic Psychology, 14, 285-316.

Teruel, P. J. G. \& Solano, P. M. (2007). Effects of working capital management on SME profitability. International Journal of Managerial Finance, 3(2), 164-186.

UBOS. (2012). Uganda Bureau of Statistics (UBOS), Statistical Abstract 2012.

Venkatesh, V. \& Davis, F. D. (1996). A model of the antecedents of perceived ease of use: Development and test. Decision Sciences, 27(10), 451-481.

Venkatesh, V. (2000). Determinants of perceived ease of use: integrating control, intrinsic motivation, and emotion into the technology acceptance model. Information Systems Research, 4(4), 342-365.

Venkatesh, V. \& Morris, M. G. (2000). Why don't men ever stop to ask for directions: Gender, social influence and their role in technology acceptance and usage behavior? MIS Quarterly, 24(1), 115-139.

Verheul, I., van-Stel, A. \& Thurik, R. (2006). Explaining female and male entrepreneurship at the country level. EIM Business and Policy Research. SCALES Paper N200510.

Wang, Y., Wang, Y., Lin, H. \& Tang, T. (2003). Determinants of user acceptance of internet banking: an empirical study. International Journal of Service Industry Management, 14(5), 501-519.

Walter, T., Balunywa, W., Rosa, P., Sserwanga, A., Barabas, S., Namatovu, R. \& Kyejjusa, S. (2004). Global Enterprenuership Monitor: GEM Uganda 2004 Executive Report.

Weir, D. R. \& Willis, R. J. (2000). Prospects for Widow Poverty in the Finances of Married Couples in the HRS. In Forecasting Retirement Needs and Retirement Wealth, edited by O. Mitchell, P.B. Hammond, and A. Rappaport (208-234). Philadelphia: University of Pennsylvania Press.

Wilhelm, M. S., Varcoe, K. \& Fridrich, A. H. (1993). Financial satisfaction and assessment of financial progress: Importance of money attitudes. Financial Counseling and Planning, 4, 181-199.

Youn, S. H. (2000). The Dimensional Structure of Consumer Buying Impulsivity: Measurement and Validation. Unpublished doctoral dissertation, University of Minnesota, Minneapolis.

Zuckerman, M., Kuhlman, D. M., Joireman, J., Teta, P. \& Kraft, M. (1993). A comparison of three structural models of personality: the big three, the big five, and the alternative five. Journal of Personality and Social Psychology, 65, 757-768. 


\section{Appendix}

Table 4: Sample characteristics

\begin{tabular}{|c|c|c|c|c|}
\hline & \multicolumn{2}{|c|}{ Female $(n=127)$} & \multicolumn{2}{|c|}{ Male (n=233) } \\
\hline & Freq & Percent & Freq & Percent \\
\hline \multicolumn{5}{|l|}{ Age } \\
\hline $18-28$ & 45 & 35.4 & 60 & 25.8 \\
\hline $29-39$ & 55 & 43.3 & 129 & 55.4 \\
\hline $40-50$ & 19 & 15.0 & 41 & 17.6 \\
\hline above 50 & 8 & 6.3 & 3 & 1.3 \\
\hline \multicolumn{5}{|l|}{ Education } \\
\hline Primary Level or less & 6 & 4.7 & 22 & 9.4 \\
\hline O' level (lower secondary) & 28 & 22.0 & 34 & 14.6 \\
\hline A' level (higher secondary) & 32 & 25.2 & 52 & 22.3 \\
\hline Vocational school (certificate) & 14 & 11.0 & 33 & 14.2 \\
\hline Diploma & 25 & 19.7 & 32 & 13.7 \\
\hline Bachelor's degree & 21 & 16.5 & 54 & 23.2 \\
\hline Master's degree & 1 & .8 & 6 & 2.6 \\
\hline \multicolumn{5}{|l|}{ Financial training } \\
\hline Yes & 62 & 48.8 & 145 & 62.2 \\
\hline No & 65 & 51.2 & 88 & 37.8 \\
\hline \multicolumn{5}{|l|}{ Past experience } \\
\hline Yes & 102 & 80.3 & 188 & 80.7 \\
\hline No & 25 & 19.7 & 45 & 19.3 \\
\hline \multicolumn{5}{|l|}{ Business sector } \\
\hline Trade & 50 & 39.4 & 94 & 40.3 \\
\hline Hotels and restaurants & 52 & 40.9 & 60 & 25.8 \\
\hline Manufacturing & 25 & 19.7 & 79 & 33.9 \\
\hline
\end{tabular}

